\title{
Insufficiency sacral fracture-dislocation mimicking suicidal jumper's fracture
}

\author{
Hosam E Matar, ${ }^{1}$ Kamran Hassan, ${ }^{2}$ Stephen P Duckett ${ }^{3}$
}

${ }^{1}$ Specialty Registrar, Department of Trauma \& Orthopaedics, Leighton Hospital, Crewe, UK ${ }^{2}$ Consultant Spinal Surgeon, Salford Royal Hospital, Salford, UK

${ }^{3}$ Consultant Trauma \& Orthopaedic Surgeon, Leighton Hospital, Crewe, UK

\section{Correspondence to} Hosam E Matar, hematar@doctors.org.uk

Accepted 12 August 2016

\section{DESCRIPTION}

Suicidal jumper's fracture is a rare transverse fracture of the upper sacrum results from fall from height and usually associated with suicidal attempts by jumping. ${ }^{1}$ A combination of flexion/extension and shearing force is responsible for this fracture, and the forces propagated through the weakest point of sacrum, the foramina. Neurological deficit involving sacral roots are common. Roy-Camille $e t a l^{1}$ first described this fracture in 1985 and classified it into three types (type 1 and 2; flexion fractures, type 3; extension fracture where the upper fragment is vertical and displaced anteroinferiorly in front of the lower fragment). These injuries are often treated surgically with reduction and spinopelvic fixation. ${ }^{2}$

Sacral insufficiency or stress fractures are rare cause of low back pain, but their occurrence is probably underestimated due to the lack of specific symptoms. ${ }^{3}$ We present a very interesting and an unusual series of MRI of a non-traumatic case of insufficiency sacral fracture dislocation mimicking this rare suicidal jumper's fracture, which we believe to be the first case in the literature.

We present a 69-year-old woman who presented with 4-week history of progressive lower back pain and difficulty mobilising independently. Her
To cite: Matar HE Hassan K, Duckett SP. BMJ Case Rep Published online: [please include Day Month Year] doi:10.1136/bcr-2016216587
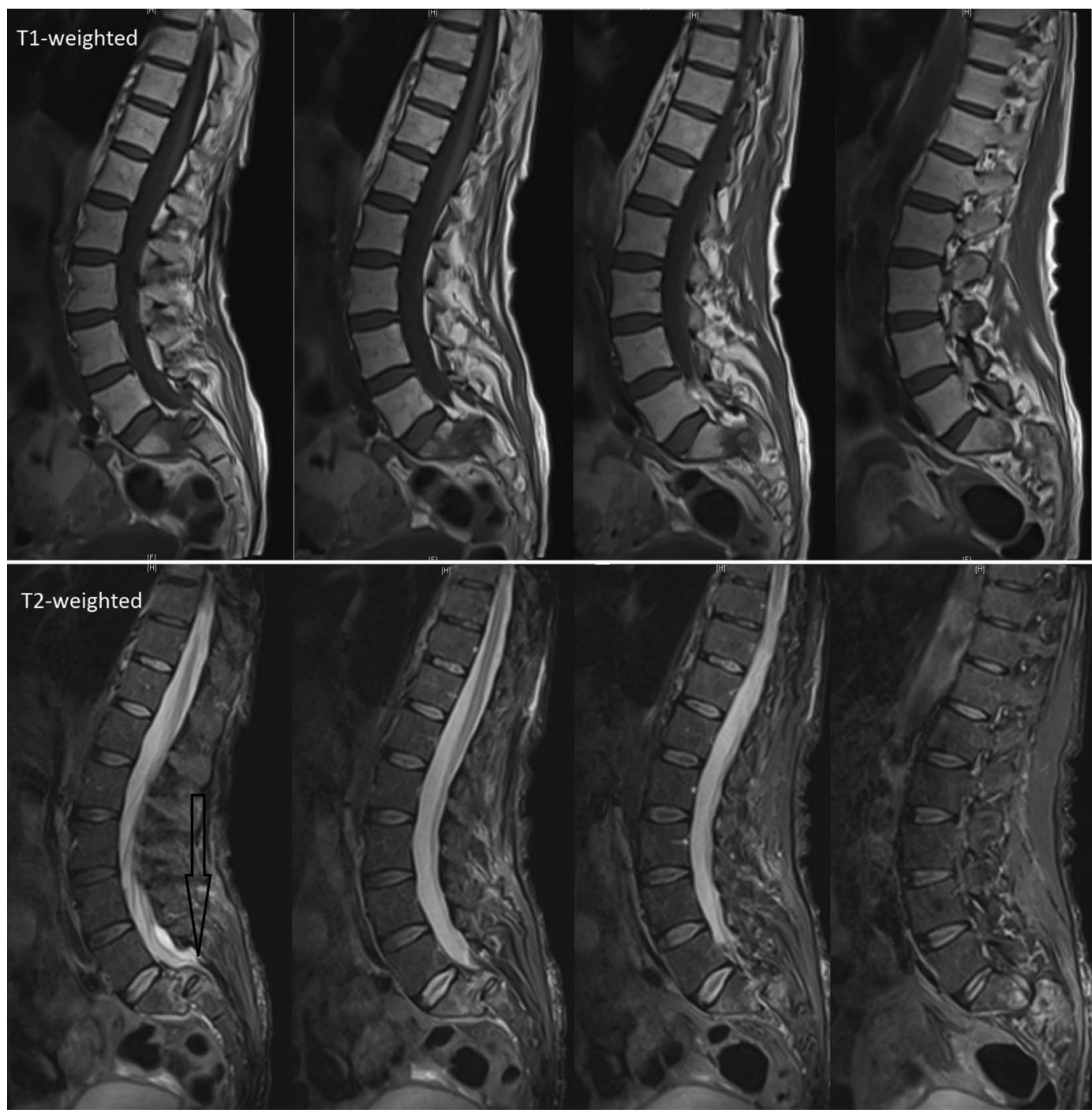

Figure 1 Sagittal images with low-signal area in T1-weighted with corresponding high-signal areas in T2-weighted images of the lumbar spine demonstrating sacral fracture dislocation with surrounding bony oedema suggestive of acute presentation. The upper fragment is displaced anteroinferiorly in front of the lower fragment in keeping with Roy-Camille type-3 fracture. 


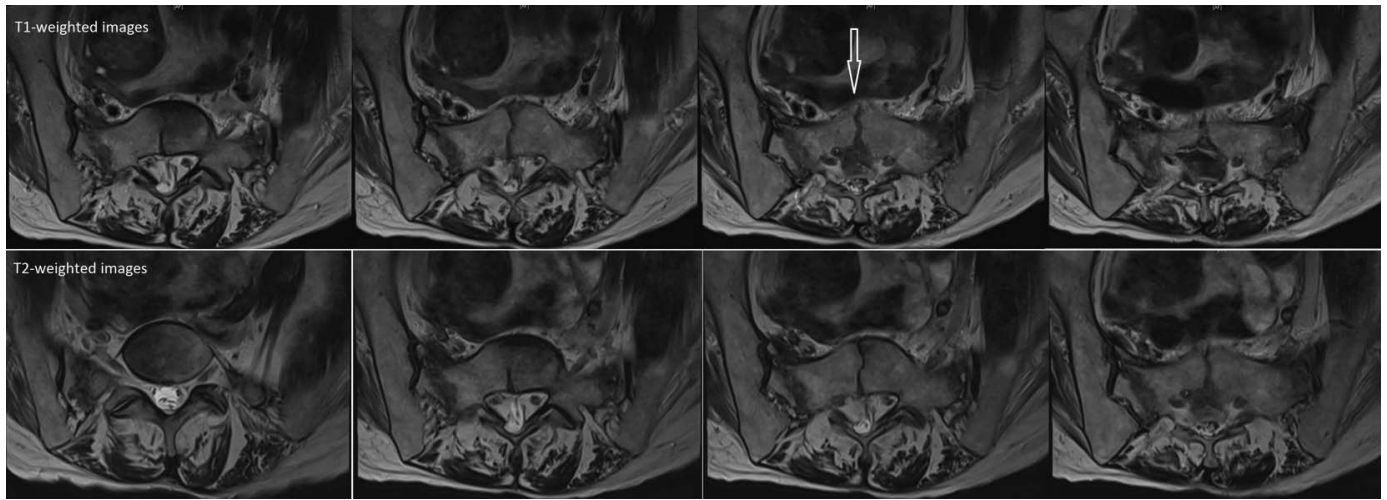

Figure 2 Axial images with T1-weighted/T2-weighted images demonstrating sacral fracture dislocation.

medical history includes osteoporosis and chronic obstructive pulmonary disease. Prior to this presentation, she mobilised independently unaided. There was no history of any trauma or falls. She had no urinary or bowel symptoms. Her musculoskeletal examination revealed lower lumbar spine tenderness. Her neurological examination revealed objective sensory deficit

\section{Learning points}

- Suicidal jumper's fracture is a transverse upper sacral fracture results from fall from height often treated surgically with spinopelvic fixation.

- Sacral insufficiency fractures are uncommon cause of lower back pain and their occurrence is probably underestimated due to the lack of specific symptoms.

- Clinicians may consider sacral insufficiency fracture in the differential diagnosis of low back and pelvic pain, particularly in elderly patients without a history of trauma.
L5-S4, motor deficit L5-S1 and diminished S1 reflex. She underwent an MRI scan (figures 1 and 2) which revealed sacral fracture dislocation in keeping with Roy-Camille type 3 injury, this was managed conservatively due to her severe osteoporosis.

Contributors HEM was involved in managing the patient and writing the manuscript. $\mathrm{KH}$ was involved in managing the patient and writing the manuscript. $\mathrm{SPD}$ is the guarantor and was involved in managing the patient, writing the manuscript.

Competing interests None declared.

Patient consent Not obtained.

Provenance and peer review Not commissioned; externally peer reviewed.

\section{REFERENCES}

1 Roy-Camille R, Saillant G, Gagna G, et al. Transverse fracture of the upper sacrum. Suicidal jumper's fracture. Spine (Phila Pa 1976) 1985;10:838-45.

2 König MA, Jehan S, Boszczyk AA, et al. Surgical management of U-shaped sacral fractures: a systematic review of current treatment strategies. Eur Spine J 2012;21:829-36.

3 Tsiridis E, Upadhyay N, Giannoudis PV. Sacral insufficiency fractures: current concepts of management. Osteoporos Int 2006;17:1716-25.

Copyright 2016 BMJ Publishing Group. All rights reserved. For permission to reuse any of this content visit http://group.bmj.com/group/rights-licensing/permissions.

BMJ Case Report Fellows may re-use this article for personal use and teaching without any further permission.

Become a Fellow of BMJ Case Reports today and you can:

- Submit as many cases as you like

- Enjoy fast sympathetic peer review and rapid publication of accepted articles

- Access all the published articles

- Re-use any of the published material for personal use and teaching without further permission

For information on Institutional Fellowships contact consortiasales@bmjgroup.com

Visit casereports.bmj.com for more articles like this and to become a Fellow 